\title{
What is being Done for Girls Who Go Wrong
}

\section{Mrs. Jessie D. Hodder}

To cite this article: Mrs. Jessie D. Hodder (1909) What is being Done for Girls Who Go Wrong, The Pedagogical Seminary, 16:3, 361-366, DOI: 10.1080/08919402.1909.10532592

To link to this article: http://dx.doi.org/10.1080/08919402.1909.10532592

册 Published online: 30 Aug 2012.

Submit your article to this journal 2

III Article views: 3

Q View related articles ๘ 


\section{WHAT IS BEING DONE FOR GIRLS WHO GO WRONG ${ }^{1}$}

By Mrs. JESSIE D. HoDdar

Social Service Department, Massachusetts General Hospital, Boston

In the few minutes at my disposal I shall not try to cover the whole field, nor to describe the broad range of activities which exist in behalf of girls in sex troubles. Rather, I shall attempt to develop certain principles which have come to me in my work at the Social Service Department at the Massachusetts General Hospital, those principles being, it seems to me, of universal application.

The physicians of the various clinics of the Out-patient send to me unmarried pregnant girls, those who have venereal diseases, those who are alcoholic, and those who have been exposed to these dangers. I shall speak here only of those who are soon to be mothers.

A conventional attitude towards such girls is well set forth, it seems to me, in the following letter wbich I care to read to you: "My dear Mrs. Hodder: The last of March I wrote to Miss C. . . . about a girl here. She was pregnant, and you advised her marrying the man who was responsible for her condition because they loved each other, and this seemed to me reasonable as, at the time, I thought it was $\mathrm{X}$. . . ., to whom she was engaged. It turns out that be is not the man. The man is a young fellow who was never in love with her-with whom she was never in love and whom she loathes. Marriage between them, under the circumstances, seemed to be adding only another wrong to the ones already committed. The girl went away, and by the advice of some one, went to a Home in Boston where her baby was born three weeks ago. She wants to leave there now-she does not want to take her baby. I do not approve of this, and I know the best thing is for the mother to have her child ; but she cannot support it, and she does not feel that she can take it and bring it up without any father.

"My appeal to you is to tell me where the child can go and what can be done with it: will you kindly write me? The

${ }^{1}$ An address before the Conference on Child Welfare at.Clark University, Worcester, July, I909. 
girl is a very interesting country girl, used to working out of doors on a farm. She is musical, sings very well, plays the piano well, played the violin in an orchestra and the organ in church. She is a high-school graduate. I do not want her to come back here. The father is a Harvard graduate, who has worked his way through college, and who is in debt. He cannot take care of the child, nor take the responsibility of its support. Will you not tell me of the name of some institution where the child can be put? Do you know of any place where the mother can go? The child might be adopted, and is probably strong and vigorous. I know you will wish the mother to keep it - I do. There is no question of her marrying the man-she would not, and be does not care to marry her, and cannot, at present."

This letter was answered as follows:

"I remember the case very well, and am glad indeed to try to answer your questions. Every situation of this kind is a difficult one to solve because we lose our calm. I do not agree with you that the girl cannot keep her baby. Think of the widows you know who are bringing up their children, who have bad no education, nothing but their hands to earn with, and untrained hands, at that. Having a baby is not like having a boil or a pimple. A poultice or time would dispose of either of the latter and leave the patient as she was Disposing of a baby does not leave either its mother or father where they were before-and what of the baby? Go look at the wards of the state-see those at the reform schools, the women in the prisuns, the boys in the reform schools and boys' prisons-and see how many of them do not know who their parents were,-they are children who have not asked to come into this world, and many of them have been shuffled off by selfish parents.

"This mother can take care of her baby, I feel perfectly sure ; and sle will be a bigger, braver woman if she does, as you realize. I can imagine no more horrible fate than to feel that my baby-my own flesh and blood-was somewhere around in the world, I knew not where. Take this girl's life so far, add this experience ( $I$ mean the sex experience), then add the experience of carrying and giving birth to her baby, plus the care she will have had of it so far, then subtract the babyput it selfisbly, brutally out of her life-and what is there left? You see we stop being twenty, and we come to be forty, and we care a lot, if our feelings are worth having. Life ceases to mean existence and comes to mean soul and all that goes to make it richer, more worth while. You and I, and every one who is belping the girl in this sorrow, must not lose sight of this and the years to come. Can there be anything more awful than to wake up and realize that one has thrown away 
an opportunity? Surely that is what would happen if that baby is given away. I have seen too many girls find in their baby all they have hungered for, to be willing to fall in with the plans of a woman who, through fear and shame, shrank from her baby and the disgrace it would bring upon her.

"How about the chance to develop the man morally? What bigger debt has he contracted in this world than his debt to bis own child? Why cannot he deny himself and spend $\$ 10$ a month towards its support? Why canuot he take out a savings bank insurance policy for $\$ 1, \infty 00$ for the child, payable at its twentieth birthday? Its mother might take out one for $\$ 500$. In the mean time, both contribute toward its support and schooling. You, or some one equally interested, might be appointed guardian for the child, and see that when it grew up it learned a trade or went to college,-its father did, you say. Say that to him. Make him feel that his baby, illegitimately born, is just as human a being, just as sensitive, just as ambitious, as a baby born in wedlock, or as he was when he struggled and worked his way through college.

"I cannot feel that the community bas any growth so long as its members are shirkers. This I am not saying to youI am saying it to all of us who turn and run from an illegitimate baby, or any other evidence of our own self-indulgence or wrong-doing.

"If we do not hold the man up to the mark in these cases, he is justified in feeling, not only that it is not immoral for him to do such things (he sees how society treats the girl), but that, by some perversion or twist of the social order, which does not apply to women, he has no obligation to his offspring. What is he on earth for, then? To whom does he owe his obligations? To society? - his child is society. To his neighbor? his child is his nearest neighbor. His child is both, and closer than both, and we must make him feel this until he aches. The girl must help us. Of course she must not marry him if they do not love each other; but unless be shares the care of the child he will see no reason why he should not seduce any and every girl his brutal selfishness leads him toward; surely, thereby, his sense of citizenship, fatherhood, and the rest, are weakened. For the sake of his moral welfare, for the sake of his child, for the sake of the next girl he may know, for the sake of the community in which be lives and upon which they would throw the care of this child, he must be made to share the responsibility of the child's support and care.

"This is a brief outline of what you must show her and him, only you will have to do it from many, many points of view, and again and again. Her community knows what has happened. She has in her heart a justification or condemnation of 
herself. Let her go back to ber community. Let her earn, and support her child, and let the best that is in her shine forth and force all to respect her. I can tell you, privately, that you can have the child adopted. I beg you not to say so to her, or let her feel that any one can take her baby but herself. Spend, please, all of your energy in boosting her up on the side of earning her living, facing her community, loving her baby; and then, if the love of her betrothed is real, he will find added to it that deep respect that comes from seeing a strong person suffer bravely-nay, gladly. The Harvard father, too, will have been made a co-sufferer, and therefore a richer, better man."

No mention is made here of her family, because in a former letter, it had been indicated that she had none. It is, bowever, my habit during the first talk with a girl after she has learned the doctor's diaguosis, to try to get at her attitude toward her family, her mother, herself, her child and society. I usually find that she has not confided in her mother, and I attempt to establish that confidence. The results of this are sometimes most happy, and solve the whole problem.

$\mathrm{X}$. . . a tall, sensitive girl, a faithful worker in a factory, the main support of the family, was fond of dancing, and fond of the young man she went with. Her whole thought when she knew of her condition was to leave home, and bide. Her people were "black" (meaning bigoted), she said, and would turn her out. I saw and talked with her mother and she was, on the contrary, kind and helpful. She was troubled and frightened, of course, but there was no thought of turning her daughter out. The older sister saw the young man in question, to whom $\mathrm{X}$. . . had been ashamed to speak. He was nuch disturbed to think she had suffered alone, and they were married at once.

If marriage is desired by both parties, I try to help it along; but I should never recommend forcing it. I always see the men in question unless they run, which they mostly do. Those who do come to my home are those who care for the girl. They are so grateful for a talk about a higher standard of sex relations. I have felt in their responsiveness a deeper hope than in almost anything else. If they can be so eager to learn the truth and the ideal about the human body and the sex relations, why does not that show us that, had they been taught early enough, they, at least, would not have joined the ranks of those who seduce innocent girls?

The next point $I$ wish to make is about the feeble-minded girl. All of us who are in this work should study, and be able to recognize the feeble-minded girl, -I mean the border-line case. She can be self-supporting in an institution, and happy there. She is an easy prey to base men; I should recommend 
taking almost any degree of trouble in order to put her under custodial care.

But if we assume that a girl is normal, merely reconciling her to her home does not solve the problem. Pregnancy in unmarried girls is not a mere accident. Frequently she has fallen into fault because she is weak and needs building up in character. In this process mother love is a mighty power, but a girl needs outside help as well, for her way is terribly hard. Over and above the social brand which she must carry, to get onto her feet, and support not simply herself, but her child, is a vast undertaking.

Y . . . was betrayed by the "man of the house". She had been engaged for five years to a man she loved. She wanted an abortion when she came to me, meaning, after it was over, to go to her home and marry her betrothed. When she found what an abortion meant she gave it up and planned to give her baby away and then marry her lover without a word of confession. She was backed up in this by the father of her child.

$Y$. . . and I have now known each other for over a year. She is a faithful and true mother to her baby, and plans to tell her lover the truth when he comes from their far-away home. I prosecuted the father of her child, and with her consent bave put the $\$ 500$ settlement money in the bank at interest, for the baby's education. I am his legal guardian, and we plan - she and I-to give him as good an education as he will take. She is earning bis and her living at ladies' fine laundry work. She and I have had many a pleasant afternoon ironing together when it has been necessary to teach her to do the more complex pieces of work. Sometimes I have ironed with the baby across my lap when there was rush work to do, or he was restless. It has been a long, slow, patient process, teaching her ber duty toward womankind and its ideals. It is like nursing a sick child into health; and it is a comfort to have her realize how far she has gone, and to see her look back and wonder how she could ever have felt as she once did.

Still more difficult is the case of $Z$. . ., for over and above the care of her and ber child, the entire family needed working with. The trouble here lies a generation back; the father is feeble-minded. Society should never have allowed such a man to bring a family into existence nor to bear the responsibility of it. He has had to be put on probation for drinking and non-support. Inadequate food supply, anxiety and overwork brought the mother to drink. There are six children, all of whom are in my care for medical and moral reasons.

I have dwelt upon the growth that can come in a woman who clings to her child and rears it in the face of heavy odds. But that growth does not come of necessity; hence: 
(a) The social worker should not assume that mother love and ability to care for the child is just a natural process that will come to pass if society does not interfere; but, on the contrary, every step should be taken to see that the mother love and capacity to care for the child does develop and that the burden is not heavier than an unaided girl can carry.

(b) If the mother proves to have no moral fibre, or, at any rate, if moral fibre does not develop, and the outlook is that the baby will be dragged into the gutter along with the mother, then the mother and child should be separated, and the child provided for as best one may. While a good mother is the best thing in the world, a bad mother comes near being the worst, and we should not be sentimental about the mere fact of motherhood. Society is coming more and more to recognize itself as over-parent, and should demand that every child in the natural home shall be reared as a good citizen. In these illegitimate children, with only half a home to start with, it is a clear duty to enforce this standard; and just crudely to leave every illegitimate child with its mother, good or bad, capable or incapable, devoted or criminally careless, would be a wrong to many children and to the state.

My last point - and I wish it might be a strong one-is the need of protection for immigrant girls. Inmigrant girls are peculiarly exposed. Many of this class come to me-perhaps about half the number I receive in a year. As prevention is better than cure, steps should be taken to safeguard better the friendless young girls who come in such numbers to our country. The men they meet tell them this is a land of liberty (in the sense of loose morals), that "all women in America are immoral". If early in their experience they get some such blow as motherhood we can do much for them; those who escape that become more and more reckless, they go the way of drink, promiscuity and the like, and are most difficult to do anything for.

These girls often come equipped with a trade of distinct value to our country, and from lack of opportunity drift into inferior work and inferior moral standards. I knew of a young girl who, recently, landed in Boston; she was fortunate enough to come to the notice of one of our splendid women who knew that she was an expert in the making of real lace. The things she made were works of art. Why let her drift into second-rate housework, where too few of us teach high standards, when she possesses skill in a trade distinctly beautiful?

Could we not, each and all of us, feel that it is our duty as citizens of the world to help these girls to the right thing when they land? And could we not, too, teach the men they meet a different ideal of American womanhood? 